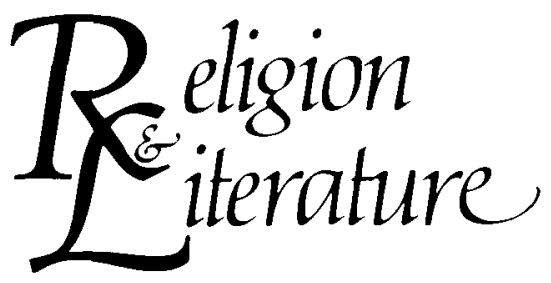

$R \mathcal{E} L$ is the forum for an on-going discussion of the relations between two crucial human concerns, the religious impulse and the literary forms of any era, place, or language.

We publish three times a year: four scholarly articles in each issue, as well as review essays and book notices. Each year one special issue is devoted to a single theme or area:

1984: An investigation of sacred experience and word in Jewish traditions, edited by Elie Wiesel.

1985: The role of language, literature and the imagination in the life and writings of Simone Weil.

1987: Religion, literature and politics.

1988: The literature of Islam.

1989: Contemporary American Fiction.

$R E L$ has published work by:

M.H. Abrams

Thomas J.J. Altizer

Felicia Bonaparte

Robert MacAfee Brown

Donald Davie

Robert Detweiler
Louis Dupré

Stanley Hauerwas

Hugh Kenner

Joseph Mazzeo

Sallie McFague

Chaim Potok

- and many other thinkers concerned with the intersection between language and the ineffable.

Religion and Literature is a key source for anyone interested in these expressions of the human spirit.

\section{Religion and Literature}

Department of English

University of Notre Dame

Notre Dame, IN 46556, USA

Name

Address
Individual Rates:

1 year: $\$ 15.00$

2 years: $\$ 27.00$

3 years: $\$ 38.00$

Add $\$ 3$ per year for addresses outside the United States.

For library rates, please inquire. 


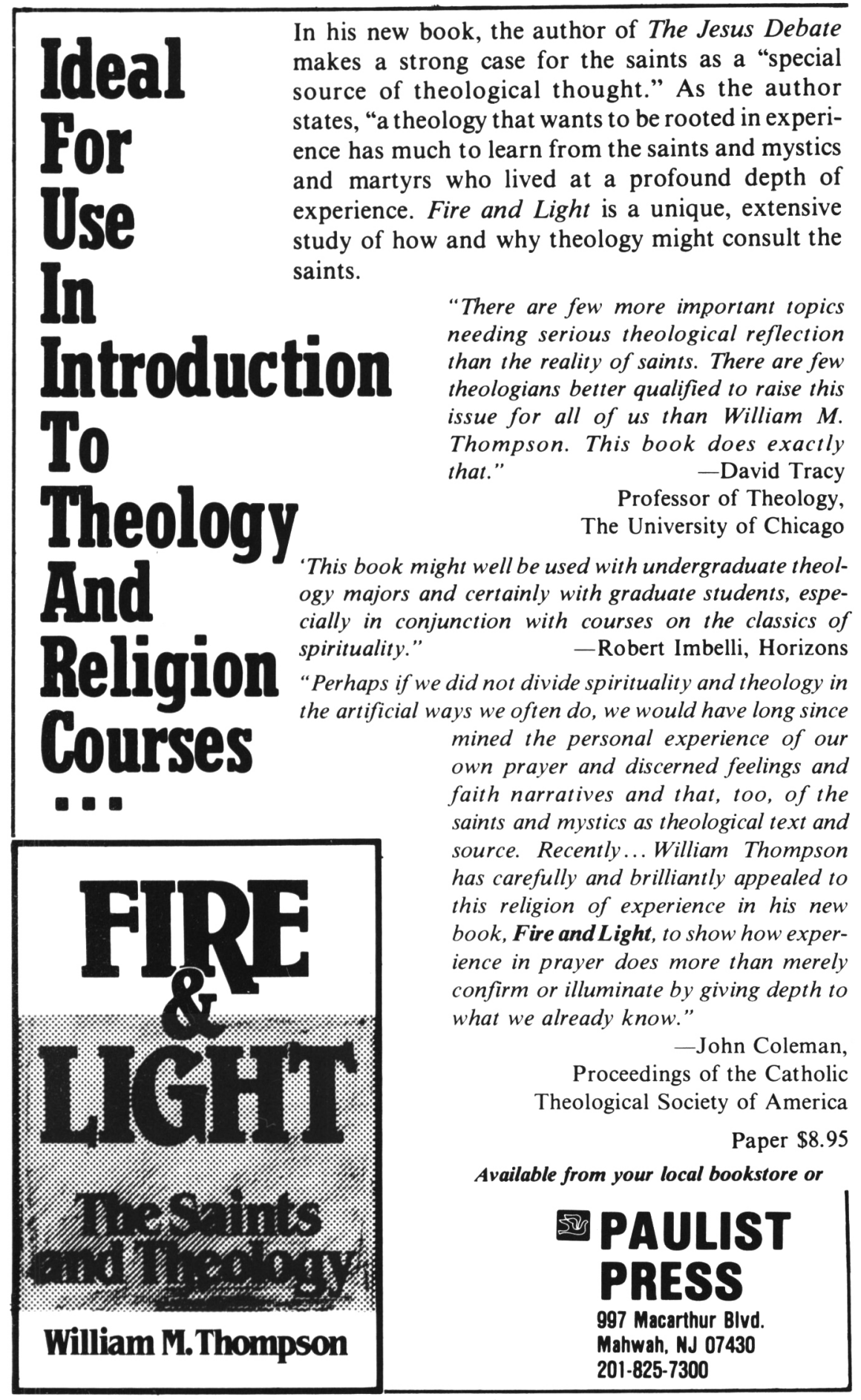




\section{LKUSDKUAU/LUIV IIIVUUIVI CROSSROAD/CONTINUUM CROSSROAD/CONTINUUM}

\section{Outstanding New Books in Religious Studies}

Hans Küng and David Tracy, editors

PARADIGM CHANGE IN THEOLOGY

This indispensable source of expert opinion inciudes contributions by Gregory Baum, Leonardo Boff, Langdom Gilkey, Martin Marty, Johann Metz, and Jürgen Moltmann. $\$ 34.50$

\section{Karl Rahner}

\section{FAITH IN A WINTRY SEASON}

Conversations and Interviews

In the Last Years of His Life

Paul Imhof, Hubert Biallowons \&

Harvey D. Egan, editors

Picking up where Rahner in Dialogue left off, this revealing collection of thirty-one interviews covers topics from liberation theology and Marian devotion to diabolical possession and exorcism. $\$ 19.50$

\section{Wolfhart Pannenberg}

\section{CHRISTIANITY IN A SECULARIZED WORLD}

One of the world's leading theologians offers a prescription for combating the present challenge of secularization. $\$ 14.95$

\section{John Drury}

\section{THE PARABLES IN THE GOSPELS}

An investigative look at the historical and literary significance of the parables in the Old and New Testament.

"An important and engaging study."

-Theological Studies

$\$ 8.95 \mathrm{pb}$
Jay P. Dolan with R. Scott Appleby, Patricia Byrne \& Debra Campbell

\section{TRANSFORMING}

PARISH MINISTRY

The Changing Roles of Catholic Clergy, Laity, and Women Religious

A lively account of how changes in ministry have affected the shape and agenda of the American Catholic parish. $\$ 27.50$

Leo J. O'Donovan \& T. Howland Sanks, editors

\section{FAITHFUL WITNESS:}

Foundations of Theology for Today's Church

Twelve leading theologians provide a carefully developed treatment of the fundamentals of Roman Catholic theology today. $\$ 19.50$

John Boswell, Daniel C. Maguire,

Rosemary Ruether \& Others Jeannine Gramick, editor

HOMOSEXUALITY

IN THE PRIESTHOOD AND RELIGIOUS LIFE

This unique book presents candid first person narratives of the lives and ministries of gay priests and brothers and lesbian sisters as well as analyses of the historical and theological dimensions of homosexuality in the religious life. $\$ 12.95 \mathrm{pb}$

\section{Virginia Ramey Mollenkott}

WOMEN, MEN AND THE BIBLE New Revised Edition

"A basic primer for studying what Scripture really presents about the nature of God and the relationships between men and women." -The Other Side $\$ 7.95 \mathrm{pb}$ 


\section{CKUSDKUAU / LUIV I IIVUUIVI CROSSROAD / CONTINUUM}

\section{New Books in Religious Studies}

\section{Prakash N. Desai}

\section{HEALTH AND MEDICINE IN THE HINDU TRADITION}

Coming this Fall

The Hindu contribution to " series that promises to enhance the well being of us all." -The Christian Century $\$ 19.95$

Maurya P. Horgan and Paul J. Kobelski

\section{TO TOUCH THE TEXT}

\section{Biblical Studies in Honor of}

Joseph A. Fitzmyer

This collection of writings by twenty-five leading scholars sheds new light on ancient texts in the Bible and its milieu. $\$ 34.50$

\section{Hans Georg Gadamer}

New and Revised Edition

\section{TRUTH AND METHOD}

Revised and Edited by Donald G. Marshall and Joel $C$. Weinsheimer

The classic of hermeneutic analysis in a newly revised edition.

"A major book." - Library Journal

"Highly recommended."-Choice

Lively and readable church history

Jean Comby

HOW TO READ

CHURCH HISTORY volume I From the Beginnings to the Fifteenth Century

$\$ 12.95$ paperback

Jean Comby and Diarmaid MacCulloch HOW TO READ CHURCH HISTORY volume II From the Reformation to the Present Day $\$ 14.95$ paperback

These two volumes provide three features that are

unique from other histories of the church-they do not separate church history from the wider history of the world, they use line drawings and photographs to tell their story, and they provide direct quotations from significant source documents.

\section{Brian Wren \\ WHAT LANGUAGE SHALL I BORROW? \\ God-Talk in Worship: \\ A Male Response to Feminist Theology}

An internationally known writer of hymns shows how God can be reimagined and named anew while keeping in continuity with the Christian faith.

$\$ 18.95$

\section{Rebecca S. Chopp}

\section{THE POWER TO SPEAK}

Feminism, Language, God

An important new feminist theologian provides an in-depth view of the emerging Word as ultimately freeing, women and likewise men, to be their true selves. $\quad \$ 17.95$

Thomas C. Oden

\section{MINISTRY THROUGH WORD AND SACRAMENT} Classical Pastoral Care Volume III

An essential resource for ministers-this volume presents brief commentary from the most indispensible texts of pastoral writers prior to the eighteenth century.

$\$ 19.95$

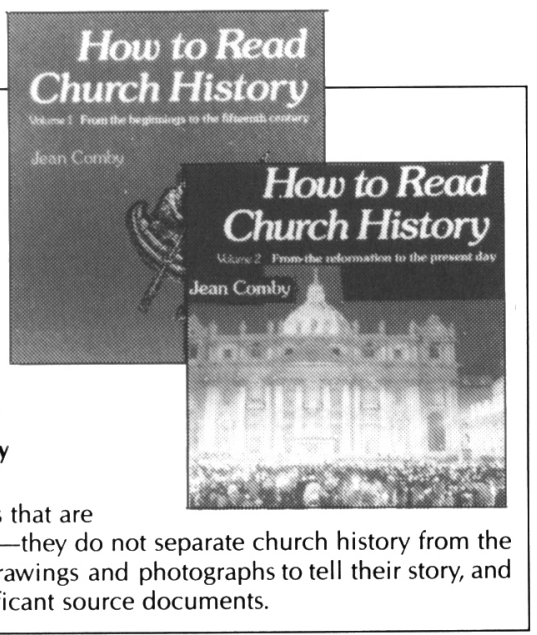

At your bookstore or call 1-800-242-7737

\section{CROSSROAD/CONTINUUM}

370 Lexington Avenue, New York, NY 10017 


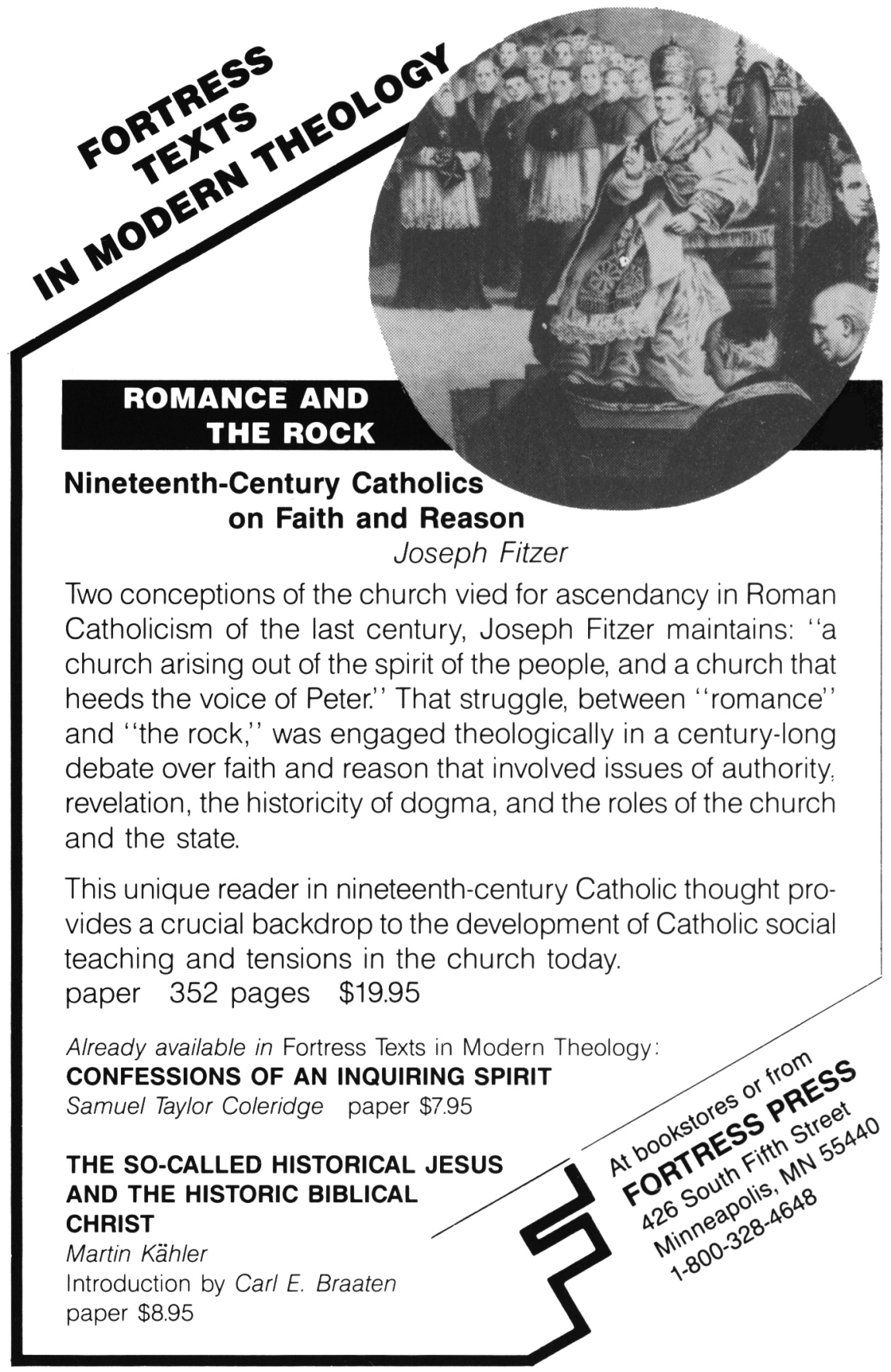




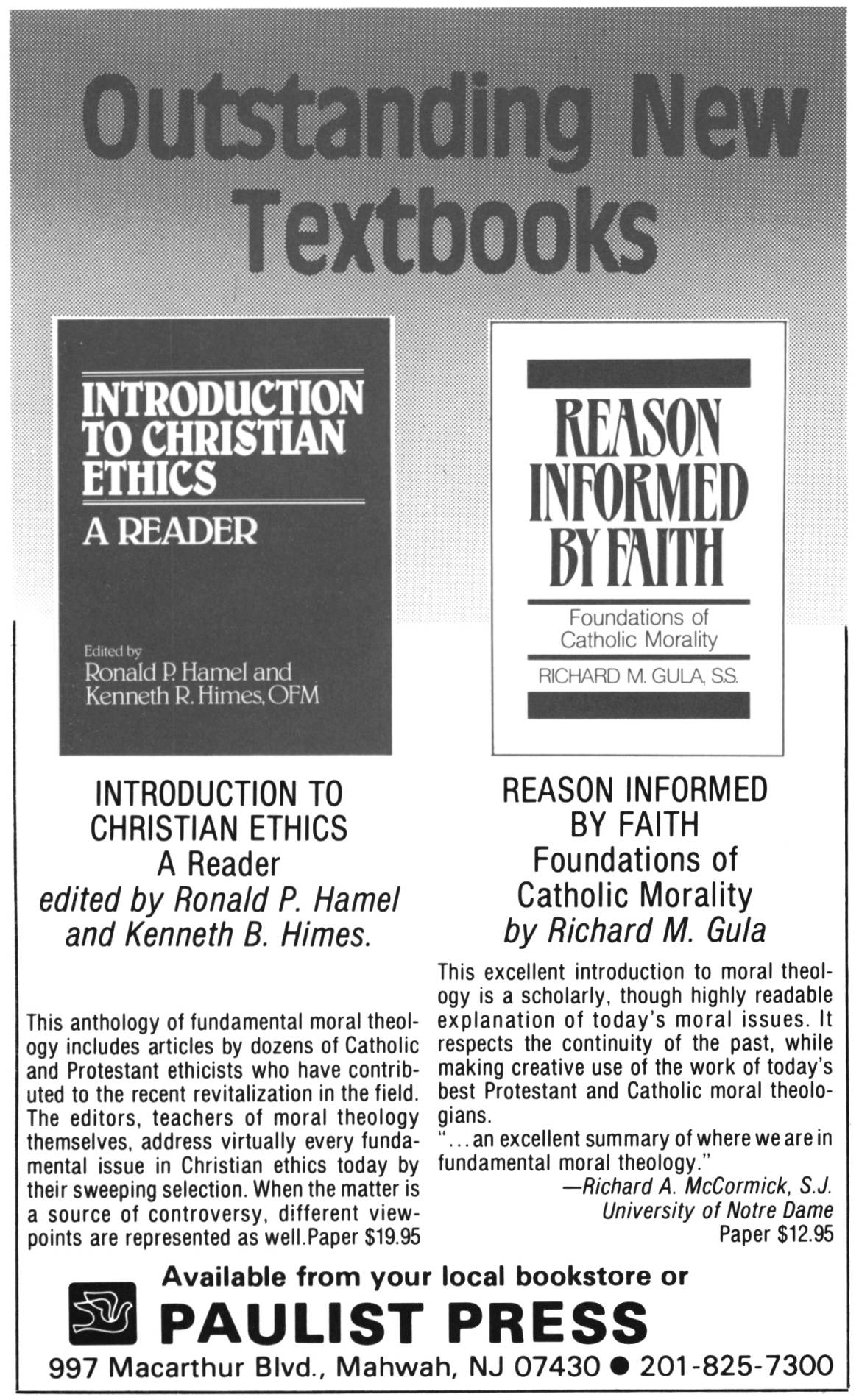




\section{NEW THEOLOGY SERIES}

\section{General Editor: Peter C. Phan}

Consultants: Monika Hellwig, Robert Imbelli, Robert Schreiter

This new 8-volume series brings us the seasoned fruits of modern scholarship. The authors are personally and pastorally aware of the theological concerns and challenges of our time and are attuned to the needs of contemporary students.

The Trinity of Love

A Theology of the Christian God

Anthony Kelly, CSSR \$16.95

Visions of a Future

A Study of Christian Eschatology

Zachary Hayes, OFM $\$ 14.95$

Other volumes to follow by Brian McDermott; Stephen Duffy; George Tavard; John F. Haught; Robert Masson; and Peter C. Phan.

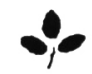

Creation \& Redemption

Gabriel Daly, OSA

$\$ 15.95$

Tradition \& Transition

Historical and Theological Perspectives of Vatican II

John O'Malley, SJ

$\$ 12.95$

Toll free $1-800-541-4420$

Michael Glazier

Wilmington, DE 19805 